\title{
A Comprehensive Update on Vascular Dementia: Types, Risk Factors and Management
}

\author{
Anil Kumar Sahdev ${ }^{*}$, Bhawana Sethi, Amarjeet Singh \\ Innovative College of Pharmacy, Greater Noida, Uttar Pradesh, India
}

\begin{abstract}
Address for
Correspondance

Anil Kumar

Sahdev,

anilsahdev20

a,gmail.com
\end{abstract}

Received:

19.01.2018

Accepted:

18.03.2018

\begin{abstract}
Vascular Dementia comprises a group of mixed dementing disorders due to cerebrovascular insufficiency and impaired blood supply to the brain. It can be divided into different types depending on the nature of the vascular disease. Indeed, any condition which causes the circulation to the brain to be impaired or damaged carries a risk to mental disabilities. The main causes of vascular cognitive impairment (VCI) are severe hypoperfusion, stroke, high blood pressure (hypertension), large vessel disease (cortical), small vessel disease (subcortical vascular dementia), strategic infarct, haemorrhage (microbleed), vasculopathy (CADASIL) and angiopathy (CAA) that consequently reduces the cerebrovascular perfusion. Further emerging evidences also provides the basis that vascular dementia is associated with metabolic disorders such as diabetes mellitus, dyslipidemia and hyperhomocysteinemia. This review gives an update on the types, risk factors and treatment of vascular dementia. (c) 2018 iGlobal Research and Publishing Foundation. All rights reserved.
\end{abstract}

Cite this article as: Sahdev, A.K.; Sethi, B.; Singh, A. A comprehensive update on vascular dementia: types, risk factors and management. Indo Global J. Pharm. Sci., 2018; 8(2): 41-54.

Keywords Dementia; CADASIL; White Matter Lesions; Hemorrhagic.

\section{INTRODUCTION}

Vascular dementia $(\mathrm{VaD})$ is a progressive disease and is caused by reduced blood supply to brain regions which are involved in cognitive functions resulting from cerebrovascular disease and ischemic and hemorrhagic brain injury [1] Vascular dementia accounts for about $17-20 \%$ of all dementia patients and is the second leading form of dementia after Alzheimer's disease (AD) [2] Globally, $\mathrm{VaD}$ is more common in men, especially before age of $75 \mathrm{yrs}$ in contrast to Alzheimer's disease (AD) that predominates in women. Incidence of overall dementia (1000 person-years) is suggested to be 32.3 which include $\mathrm{VaD} 9.5$, AD 14.6, Lewy bodies dementia 1.4, mixed type 3.8, and dementia other types 3.1. In Western countries and Japan, the prevalence rate of vascular dementia is $1.5 \%$ and $2.2 \%$, respectively. A Swedish study estimated the lifetime risk of $\mathrm{VaD}$ as $34.5 \%$ for men and $19.4 \%$ for women.
In community-based studies, the incidence of $\mathrm{VaD}$ has ranged from 0.17 to 0.71 per 100 person years [3-4].

Various risk factors for $\mathrm{VaD}$ have been reported including age, diabetes, obesity, hypertension, cigarette smoking, hyperlipidemia, cardiac arrhythmias, coronary artery disease, and autoimmune disorders such as cerebral arteritis or lupuserythematosus [5-6]. Despite of the fact that $\mathrm{VaD}$ is highly prevalent memory disorder, only limited therapeutic interventions are currently available to manage $\mathrm{VaD}$ [7].

Types and Classification of Vascular Dementia On pathological basis vascular dementia can be classified as:

\section{(A) ACUTE - ONSET (POST STROKE) VaD}

\section{1) Large - vessel vascular dementia}

i) Multi-infarct $\mathrm{VaD}$ 
Indo Global Journal of Pharmaceutical Sciences, 2018; 8(2): 41-54

ii) Strategic infarct $\mathrm{VaD}$

\section{2) Small - vessel vascular dementia}

i) Subcortical ischemic $\mathrm{VaD}$

a) Binswanger's disease

b) Lacunar dementia or Lacunar state

c) CADASIL

ii) Cortical-Subcortical

\section{3) Hemorrhagic VaD}

\section{4) Ischemic - Hypoperfusive VaD}

\section{(B) SUB-ACUTE VaD}

\section{(A) ACUTE-ONSET (POST STROKE) VASCULAR DEMENTIA}

Post stroke vascular dementia (PSVD) is defined as a type of dementia that occur after stroke. The prevalence of PSVD varies from 6 to 32\% [8]. PSVD patients have a decreased ability to perform certain executive functions [9-10] like working memory, planning, orientation and problem-solving [11]. PSVD generally involves cerebral infarction infrontal, and temporo-occipital infarction, basal ganglion, thalamic, left hemisphere and cerebral white matter lesions [12].

Acute onset (Post stroke) vascular dementia may be of several types:
1) Large vessel vascular dementia

(i) Multi-infarct dementia (MID)

Multi-infarct dementia is characterized by microinfarcts and multiple lacunar as well as infarcts of variable sizes (large and small) in the cortical and subcortical areas [13]. The infarcts may be caused by atherosclerosis in the circle of willis, embolic events and also by CAA and SVD. The hemorrhages associated with CAA and SVD may contribute to overall brain damage and are significant for this type of $\mathrm{VaD}$ [14-16]. Clinical features of MID include sudden onset of cognitive symptoms, deterioration of mental functioning, focal neurologic symptoms and evidence of cardiac and vascular disease [17-18]. It is more common in men than women and affects the people between the age group 60-75. Persons with history of hypertension, atherosclerosis, smoking, stroke, diabetes mellitus and obesity are at high risk of MID [19].

\section{(ii) Strategic infarct dementia}

Strategic infarct dementia is caused by a single major stroke that damages hippocampal neurons resulting in marked cognitive deficits [1]. The primary brain areas involved in this type of $\mathrm{VaD}$ include thalamus, basal forebrain, and caudate [20-21]. It has been reported that large strokes; lacunar infarcts; and microinfarcts in the hippocampus and the paramedian nuclei of the thalamus would result in the strategic infarct dementia $[13,15]$.

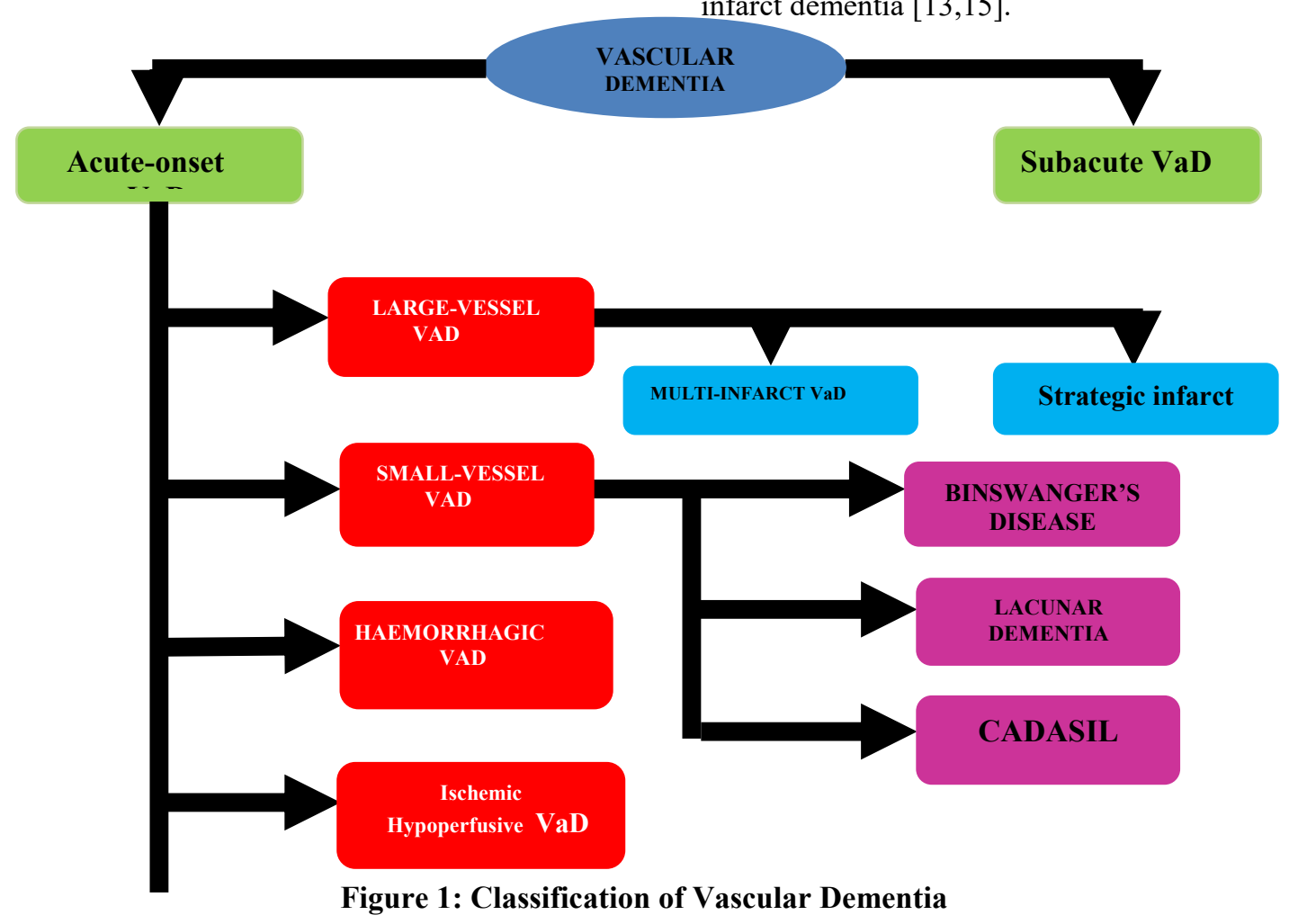



Small vessel vascular dementia

\section{(i) Subcortical ischemic vascular dementia (SIVD)}

Subcortical ischemic vascular dementia is a subtype of vascular cognitive impairment (VCI) and related to cerebral small vessel disease [22-23]. SIVD caused by chronic hypoperfusion because of small artery disease and the pathological changes involve development of ischemic white matter lesion, glia activation, and profound cognitive impairement[24-25]. Hypertension is the most important leading risk factor of SIVD others are ageing and diabetes mellitus [23]. It further incorporates three clinical entities: Binswanger's disease; lacunar state and CADASIL.

\section{a) Binswanger's disease (Subcortical vascular encephalopathy)}

Subcortical vascular encephalopathy describes ubiquitous demyelination and axon loss in the white matter sparing Ufibers, i.e. confluent white matter lesions [13]. White matter lesions (atrophy) can be caused by chronic hypertension as well as in old age. The disease is characterized by loss of memory and intellectual functions along with significant changes in mood [26]. Binswanger's disease targets the vessels in the zone of the subcortex, excluding the capillaries and microcirculation's vessels [27]. Binswanger's disease yet no cure and shown to be the most severe destruction and impairment of all type of $\mathrm{VaD}$ [28].

\section{b) Lacunar dementia}

Lacunes are miniature, round or oval subcortical infarcts from 3 to $20 \mathrm{~mm}$ size. Clinically, these may be silent or may be followed by a history of transient ischaemic attack or stroke [29]. Lacunar infarct is a type of stroke resulting from occlusion of one of the penetrating arteries which provide blood to the brain's deep structures [30]. Lacunes are subsequently found at the level of the lenticular branches of the anterior and middle cerebral arteries, the thalamogeniculated and thalamoperforating branches of the posterior cerebral artery and the paramedian branches of the basilar artery. This infarct is an important predictor of poststroke cognitive decline and vascular dementia [31]. Ischemic lacunar stroke represents five recognized features: sensorimotor syndrome, pure motor hemiparesis, dysarthria, pure sensory syndrome, ataxic hemiparesis and clumsy hand [32-33]. The main risk factors for lacunar infarcts are hypertension and diabetes [33-34].

\section{c) CADASIL (Cerebral autosomal dominant arteriopathy)}

CADASIL is monogenic small vessel disease caused by destruction of vascular smooth muscle fibrous thickening of arterial wall and characterized by gradually diffuse bilateral subcortical WMH (White matter hyperintensities) and lacunes[35]. CADASIL with subcortical infarcts and leukoencephalopathy is caused by genetic mutation in the NOTCH 3 gene on chromosome 19[1]. The NOTCH3 receptor mainly found in adult vascular smooth muscles cells (VSMC). Main function of VSMC is related to the maintenance of vascular structural and functional stability. CADASIL is suggested to result in psychiatric disorders, especially mood changes associated with the development of cognitive impairment[36]. It commonly begins with migraine headache, recurrent subcortical infarcts and subcortical dementia followed by minor strokes in mid-adulthood[36-37].

\section{(ii) Cortical-subcortical}

It is characterized by sudden onset of unilateral sensorimotor changes along with agnosia (cortical cognitive impairments), apraxia or aphasia. Most of the patients have an executive dysfunctioning as a consequence difficulties in areas such as intiation, planning and organization of activities[38]. Patient diagnosed for cortical-subcortical dementia is characterized by applause sign (motor abnormality) by asking the patient to quickly claps his/her hands for a number of times and is considered to be positive when the subject is incapable to stop, and violates the constraint[39].

\section{3) Hemorrhagic vascular dementia}

Intracerebral hemorrhage (ICH) results bleeding into the brain parenchyma because of rupturing small vessel, affected by sporadic microangiopathies. The cognitive impairment after ICH consists of both the abrupt cognitive deficits as well as subsequent cognitive deterioration driven by slowly accumulating diffuse vascular and non vascular pathology[40]. ICH have higher risk of morbidity and mortality, represents $10-15 \%$ of all strokes and more common ischemic forms of stroke [41-42]. Many studies have suggested that dementia may a predictor of mortality in ICH survivors[43]. ICH located in deep brain regions especially in thalamus or putamen[44-45] and in lobar locations resulting from rupture of small and medium size arterial perforators in the cortex and subcortical white matter[46]. ICH usuallyoccur in the age 45 to 64 and $37-38 \%$ patients die in 30 days[47].

\section{4) Ischemia-hypoperfusive vascular dementia}

Hypoxic/anoxic brain injury resulting from insufficient cerebral blood flow, reduced oxygen availability, reduced oxygen carried by blood or metabolic interference with the use of available oxygen[48]. The grey matter of the brainstem is greatly resistant to hypoxia and can survive after relatively severe ischemia; however, prolonged anoxia is documented to elicit extensive cortical damage[49]. The ischemic-hypoxic 
Indo Global Journal of Pharmaceutical Sciences, 2018; 8(2): 41-54

state is characterized by membrane depolarization, brain edema, cellular energy failure, excess neurotransmitter release (excitatory amino acid neurotransmitter) and uptake inhibition, increases in intracellular calcium, lipid peroxidation, production of oxygen free radicals, and disturbances in autoregulation of cerebral blood flow at the micro or macroscopic levels[50-51]. The main characteristics of diffuse anoxic-ischemic encephlalopathy's is ischemic-hypoxic dementia and is distinguished by restricted injury due to selective susceptibility i.e. incomplete white matter infarction, medial temporal lobe sclerosis, and border zone infarction[52].

\section{(B) SUB-ACUTE VaD (SVD)}

Subacute vascular dementia is characterized by extensive white matter hyperintensities (WMH) and multiple lacunar infarcts[53]. SVD patients show brain atrophy and other neurodegenerative changes leading to cognitive deficit and reflect a combination of degenerative and ischemic causes[52,54-55]. Cerebrovascular lesions in the subcortical region cause episodic deterioration in executive functioning, mood changes (depression, personality changes, emotional liability), and abstract thought[38]. Subcortical VaD associated with more extensive white matter lesions, less severe hippocampal atrophy and the absence of CAA (Cerebral amyloid angiopathy), indicated radiologically by lobar bleeds, cortical subarachnoid hemorrhage and cortical microinfarctions[56].

\section{Risks Factors}

The vascular risk factors associated with dementia can be divided into two groups: Modifiable factors and Nonmodifiable factors.

Modifiable: Factors includes hypertension, diabetes mellitus (DM), ischemic heart disease (IHD), peripheral vascular disease (PVD), white matter lesions, hyperlipidemia[1,57-61].

Non-modifiable: Factors are gender and age (both incidence and prevalence of $\mathrm{VaD}$ increases with age and usually higher in men) [38,62].

\section{a) Diabetes Mellitus}

Many studies have shown that type 2 diabetes have a 1.5-2.5 times greater risk of vascular dementia and other form of dementia[63-64] and currently one in 10-15 cases of dementia can be attributed to diabetes[59,65].Research has proved that the brain is not used glucose properly in the people of diabetes and its associated dementia. This may be due to nerve cell death, which decreases the brain's ability to interpret messages. In the case of vascular dementia, brain cells die due to lack of oxygen, preventing brain cells from communicating with each other [66].

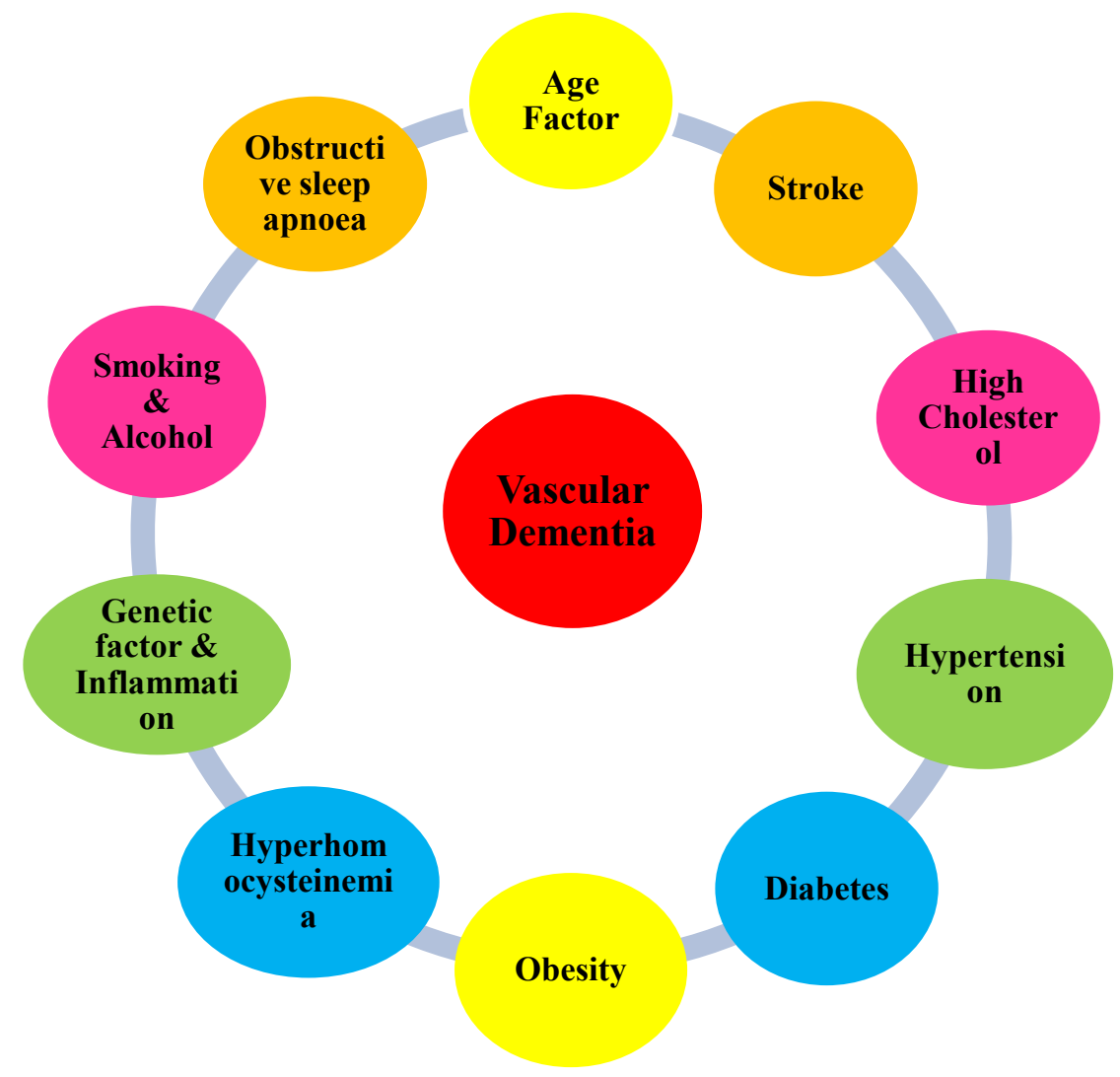

Figure 2: Risk factor for Vascular Dementia 


\section{Indo Global Journal of Pharmaceutical Sciences, 2018; 8(2): 41-54}

Diabetes is a complex metabolic disorder which is closely associated with other established risk factors for dementia, such as hypertension and atherosclerotic vascular disease. Some other factors like demographic factors (e.g. age, education), diabetes-specific factors (e.g. diabetes duration and glycemic control), medication use and genetic factors may also be involved in the association between diabetes and dementia[59,63]. Genetic predisposition may also contribute to the increased dementia risk in $\mathrm{T} 2 \mathrm{M}$. The most examined genetic factor for dementia is APOE $\varepsilon 4$ allele which is related to cardiovascular disease and late onset $\mathrm{AD}$ [67]. It has been reported that interaction between APOE $\varepsilon 4$ allele and T2M, further increases the diabetes associated risk of dementia[67,68-69]. T2M and associated vascular risk factor predispose to macro- and microvascular complications throughout the body and it is an well-known risk factor for thrombo-embolic stroke, as well as cerebral small vessel disease [70].

\section{b) Hypertension}

Hypertension is one of the well-known risk factor to cause endothelial dysfunction, cognitive decline and progression of $\mathrm{VaD}$ [71-74]. In hypertension, animal studies have documented to cause significant endothelial dysfunction and memory loss[75-77].The possible hemodynamic mechanism of hypertension in $\mathrm{VaD}$ is centered around white matter damage. The aging population, untreated and uncontrolled hypertension is a high risk factor for $\mathrm{WM}$ lesions and $\mathrm{VaD}$ disease progression[1,78]. Increase in central blood pressure (BP) and pulsatile flow load to the brain, is suggested to be associated with advanced arterial stiffness and brain small vessel diseases (SVDs)[79].

\section{c) Atherosclerosis}

There is some evidence for a co-relation between atherosclerosis and vascular dementia risk. A Rotterdam study, involving 6647 subjects for upto 9 years, revealed that atherosclerosis (common carotid intima media thickness, peripheral artery disease, carotid plaques), predominantly carotid atherosclerosis is associated with an increased risk for vascular dementia[80]. Moreover, the correlation between arterial stiffness and cognition impairment has been indicated[81]. The presence of genetic variant APOE4 (apolipoprotein E4) allele, is documented to modulate LDL (low-density lipoproteins) metabolism, increase free radical formation and reduce plasma antioxidant concentrations. Collectively, these risk factors supports a mechanism for increased LDL circulation time and free radical modification of LDL. Elevated levels of lipids during mid-life has been associated with increased risk of dementia[82].

\section{Apolipoprotein $\mathrm{E} 4$ in vascular dementia-}

The apolipoprotein E (apoE) have a putative role in several diseases like hypertension, stroke, atherosclerosis, as $\mathrm{VaD}$. ApoE is polymorphic with three major isofoms, apoE2, apoE3 and apoE4, which differ by a single amino acid involving cysteine-arginine replacements at positions 112 and 158[83]. In the CNS, ApoE is produced by the astrocytes and its function to transport cholesterol to neurons via apoE receptors, which are the members of LDL receptors[84-85]. It has been proposed that ApoE is the major cholesterol transporter in the brain and hence, essential for synaptogenesis in neurons. Studies have documented potential association of ApoE polymorphism in $\mathrm{VaD}[86]$. The diet rich in high saturated fats and cholesterol produces higher risk of $\mathrm{VaD}$, and is aggravated more in people having APOE4 alleles[87-88]. Clevage of apoE increases the risk of $\mathrm{AD}$ and its associated dementia by two ways, either through a loss of function or gain of toxicity[89].

\section{d) Hyperhomocysteinemia}

Hyperhomocysteinemia is an anticipating factor for $\mathrm{AD}$ and also a common cause of dementia in elderly[90]. Hyperhomocysteinemia is associated with various medical conditions of vascular dementia[91]such as cardiovascular disorders[92], ischemic stroke[93], venous thromboembolism[94], myocardial infarction, epilepsy, parkinson's disease (PDs), multiple sclerosis and eclampsia[95]. In dementia, homocysteineprobably act as an excitatory neurotransmitter and compete with inhibitory neurotransmitter $\gamma$-amino butyric acid (GABA). Hyperhomocystinemia has been reported to induce microvascular permeability by reducing the effect of GABA$\mathrm{A} / \mathrm{B}$ receptors and increasing vascular oxidative stress[96], which further activate disintegrin and metalloproteinase. This whole process causes, disruption of matrix in the BBB and leads to $\mathrm{VaD}[95]$. There are several factors and conditions that are involved in elevated level of homocysteine, like endothelial cell injury, platelet adhesiveness, LDL cholesterol oxidation, deposition in the arterial wall[97], lifestyle factors (eating habits, smoking and alcohol consumption)[98-99],age, hypertension, renal failure and genetic factors[100].

\section{e) Alcohol and Smoking}

Long term excessive consumption of alcohol beverages is reported to cause neurological damage and destruction in cognitive function[57]. The cognitive deficit occurs due to atropic changes, lacunar infarcts, white matter lesions[101]. Chronic alcoholism produces increase in the level of triglycerides, hypertension and hypercysteinaemia (toxic to the endothelium associated with increased risk of cardiac 


\section{Indo Global Journal of Pharmaceutical Sciences, 2018; 8(2): 41-54}

disorders, strokes and arterial thrombosis), leading to high morbidity and mortality ratio)[102].

Evidences suggested that smoking also contributes to cognitive decline, the mortality associated dementia higher in smokers than the non-smokers[103-104]. Smoking is suggested to cause hyperhomocysteinaemia, oxidative stress, atherosclerosis and excitotoxicity responsible for neuronal death eventually leading to cognitive loss and dementia[105106].

\section{f) Obesity}

Obesity may enhance the risk of vascular dementia like hypertension, diabetes mellitus, dyslipidaemia, atherosclerosis, and cardiovascular disease[107-108].Weight gain and increased waist circumference and skinfold thickness are considered as increased risk factors of dementia[109]. It is reported that an increase in risk of dementia is seen among obese persons having BMI $>30$, as compared with normal weight individuals having BMI 20-25 at age 50[110]. It has been suggested that elevated level of leptin in plasma is associated with adipocyte dysfunction and increased vascular problems[111].

\section{g) Genetic Factors and Inflammation}

The gene with the highest known influence on the risk of developing late onset of Alzheimer's disease and its associated dementia is apolipoprotein E (APOE). The risk of dementia increases from $20-90 \%$ as the number of APOE4 allele increases in the age 68-84 years[112]. The changes occurs in angiotensin converting enzyme (ACE) enzyme sequences, angiotensinogen $\mathrm{T} 235 \mathrm{M}$ has also been shown to be associated with vascular dementia[113]. CADASIL (Cerebral Autosomal Dominant Arteriopathy with Subcortical Infarcts and Leukoencephalopathy) is caused by mutations in NOTCH3 gene, and has been suggested as important cause of stroke and vascular dementia[114]. Inflammation is also associated with the pathogenesis of dementia \& $\mathrm{AD}$, various inflammatory mediators (cytokines and chemokines) are reported to be involved in dementia for e.g. IL-1 $\alpha-889$ allele T significantly contributed in the late onset dementia[115]. Frontotemporal dementia (FTD) patients showed increased cerebrospinal fluid (CSF) level of tumor necrosis factor-alpha (TNF- $\square$ ) and transforming growth factor beta (TGF- $\beta$ ) [116].

\section{Management and Treatment of Vascular Dementia}

So far, US FDA has not approved any drug specifically to treat changes in judgement, planning, memory and other thought process caused by vascular dementia[1]. However, certain medications approved by FDA to treat these symptoms in Alzheimer's disease may also help people with vascular dementia to the same modest extent they help those with Alzheimer's disease.

\section{a) Cholinesterase Inhibitors}

Cholinergic structures are more prone to ischemic damage. The hippocampal CA1 region, caudate, putamen and temporal cortex are more susceptible for choline acetyltransferase activity, hippocampal atrophy is quite common in $\mathrm{VaD}[117-$ 118]. Seldon et al. reported two highly organized and discrete bundles of cholinergic fibers in human brains which extend from nucleus basalis to cerebral cortex, hippocampus and amygdala. These both pathways travel in the white matter and carry cholinergic input to the neocortex. Localized stroke may be developed in these cholinergic bundles[119]. Studies have reported significant reduction in the level of cholinergic markers in the neocortex, hippocampus and CSF that is correlated with cognitive deficit (learning and memory)[120121].

Currently there are three main AChE inhibitors which are in clinical use. Acetylcholinesterase inhibitors improve cholinergic transmission by increasing the survival of acetylcholine in the synapse and even some enhance the activity of the nicotinic-cholinergic receptor in the brain[122].

\section{a.1) Donepezil}

Donepezil is a piperidine based agent, highly selective for acetylcholinesterase and a non competitive, reversible antagonist of cholinesterase[38]. Donepezil is orally well tolerated drug and acts centrally to inhibit acetylcholinesterase reversibly and yield beneficial effect in dementia[1]. Donepezil is approved for mild to moderate $A D$ at a dose of $10 \mathrm{mg} /$ day in Europe, Japan, United States (USA) and in some other countries[123]. Further, a dose of $23 \mathrm{mg} /$ day has been approved for moderate to severe stages of $\mathrm{AD}[124]$. From the previous studies it has been demonstrated that donepezil attenuate the volume of cerebral infarction and protect against neuronal cell death and cognitive impairment, enhance adult hippocampal neurogenesis by increasing the level of cAMPresponse element-binding protein (CREB) and phosphorylation[125-128].

\section{a.2) Galantamine}

Galantamine is another cholinesterase inhibitor and approved by US FDA for AD, it modulates central nicotinic receptor to increase cholinergic neurotransmission. Two large randomized clinical trials (RCTs) were selected involving $\mathrm{VaD}$ patients and analyzed for about 6 month[129]. First RCTs included 449-543 $\mathrm{VaD}$ and $\mathrm{AD}$ patients and were treated with 24 $\mathrm{mg}$ /day upto 24 weeks. The parameters like cognition (ADAScog) and CIBIC-plus (Global), Behaviour (according to 


\section{Indo Global Journal of Pharmaceutical Sciences, 2018; 8(2): 41-54}

Neuropsychiatric inventory) and ADLs (ADCS-ADL) using the DAD (Disability Assessment in Dementia) were observed for assessing the improvement[130-131]. In second RCTs 786 subjects with $\mathrm{VaD}$ and were treated with 16-24 $\mathrm{mg}$ /day upto 26 weeks; patients showed improvement in cognition ( ADAS-cog), executive function but no significant change in global (CIBIC-plus) or behavior (according to NPI (Neuropsychiatric inventory)) and ADL (ADCSADL)[129,132-133]. Due to the adverse effect such as nausea and vomiting higher rates of withdrawl were seen. In conclusion, it has been found that galantamine improves cognitive deficit in $\mathrm{VaD}$ but the side effect suggests caution is required before prescribing it to $\mathrm{VaD}$ patients.

\section{a.3) Rivastigmine}

Rivastigmine is a second generation cholinesterase inhibitor with the capacity to inhibit both acetylcholinesterase and butyrylcholinesterase[38]. In a randomized open label one year study, 208 patients with $\mathrm{VaD}$ treated with rivastigmine, there was a slight improvement in executive function (clock drawing tests) and in behavior[134]. However more studies are needed to understand if rivastigmine could be used for treatment of vascular dementia.

\section{b) Statins}

Statins or HMG-CoA (3-hydroxy-3-methylglutaryl coenzyme A) inhibitors are a class of cholesterol lowering drugs. Statins reduce the formation and entry of LDL-C into the circulation and upregulate LDL-R activity, and thus lowering LDL-C and triglycerides and increasing HDL-C[135]. They also possess many pleiotropic effects and can improve the endothelial function of atherosclerotic vessels by decreasing endothelial 1 and angiotensin II type 1 receptors and increasing nitric oxide levels[136]. Statins are documented to have a beneficial effect in all types of dementia by several mechanisms. Two of the studies have found a significant positive effect of statin treatment on $\mathrm{VaD}$, described by the lower incidence of $\mathrm{VaD}$ in statin users. Among all cases of dementia, $\mathrm{VaD}$ is the one that is more likely to benefits from statins[137].

\section{c) N-Methyl-D-Aspartate Antagonists}

\section{c.1) Memantine}

Memantine is second class of drugs after AChE inhibitor that has been approved by FDA for AD. Memantine acts on the glutamatergic system and antagonizes the N-methyl-Daspartate receptor, and have a potential to eradicate the neurological conditions such as dementia and parkinson's disease (PD)[138]. Nmethyl-D-aspartate (NMDA) receptor is a predominant molecular device for controlling synaptic plasticity and memory function[139]. Memantine is reported to produce small benefits in cognitive functions of patients with mild to moderate $\mathrm{VaD}$. A study based on randomized placebo controlled trial tested memantine at a dose $20 \mathrm{mg} /$ day upto 28 weeks. The data analysis showed there is significant improvement in cognitive functions from baseline over placebo with no change in clinical global scale[140]. Another analysis based on 6-months clinical trials showed improvement in cognitive deficit by using the ADAD-cog. Significant improvement and less adverse effects were seen in patients who received memantine[141-142]. However clinical potential of memantine in $\mathrm{VaD}$ is still not clear.

\section{d) Non-Steroidal Anti-inflammatory Drugs (NSAIDs)}

Nonsteroidal anti-inflammatory drugs(NSAIDs) produces the anti-inflammatory action by inhibiting cyclooxygenase- 1 and cyclooxygenase- 2 and by activating the peroxisome proliferator gama (PPAR $\gamma)$ nuclear transcription factor[143144]. Cyclooxygenase-mediated oxidation is important in the calcium-dependent glutamate signaling pathway that involves N-methyl-D-aspartate. NSAIDs may be able to protect neurons directly by reducing cellular responses to glutamate[145]. In ischemic events and stroke, aspirin is widely used in the secondary prevention. A study has shown in which 70 patients diagnosed with multi-infarct dementia, administered aspirin daily at a dose $325 \mathrm{mg} /$ day or placebo for 3 years. Daily treatment with aspirin observed to improve or stabilised cerebral perfusion as well as cognitive deficit[146]. Another NSAIDs indomethacin has been shown to decrease the risk of dementia by reducing the IL-10 production[147]. However, further research is needed to confirm the effectiveness of aspirin and other NSAIDs in VaD.

\section{e) Antihypertensive Drugs}

There are two possible conditions for the reduction in cerebral blood flow which may occur usually in hypertensive patients. First, hypertension can increase systemic vascular resistance and slow down normal blood flow. Second, cerebral blood flow may fall when blood pressure is high due to direct damage to brain endothelial cells that produce a vasodilator nitric oxide[148]. Thus, the therapy used in hypertension aimed at controlling high blood pressure by using antihypertensive, increasing cerebrovascular nitric oxide, or protecting endothelial cells in brain could prevent the onset of $\mathrm{AD} \&$ dementia[149].Various antihypertensive agents such as ACE-inhibitors, $\beta$-blockers, calcium channel blockers and diuretics have been reported to lower the risk of dementia and $\mathrm{AD}[150]$. Angiotensin receptor blocker (ARB) in a recently concluded trial has been observed to reduce the risk of dementia in high vascular risk individuals[151]. Further another study with nimodipine a calcium channel blocker on $\mathrm{VaD}$ patients indicated significant improvement of Sandoz Clinical Assessment Geriatrics (SCAG) scores, global function and cognitive functions[152]. 


\section{Indo Global Journal of Pharmaceutical Sciences, 2018; 8(2): 41-54}

\section{f) Miscellaneous}

\section{f.1) Phosphodiesterase (PDE) Inhibitor}

There are few reports implicating efficacy of Phosphodiesterase (PDE) inhibitors in dementia. Pentoxifylline a non selective PDE inhibitor have been reported to exert beneficial effect in patients with multi infarct dementia[153,154]. Animal studies have shown efficacy of cilostazole a PDE-3 inhibitor in diabetes induced memory deficits[155]. Inhibitors of PDE-5 and PDE-4 have shown potential anti-inflammatory[156], neuroprotective, antioxidative[157] and memory enhancing effects[158]in recent studies. Animal studies have shown great potential of PDE as important pharmacological target for the management of dementia.

\section{f.2) PPAR (Peroxisome Proliferator activated receptor) gamma agonists}

These agents are well reported to possess many other actions viz. anti-inflammatory, antioxidative, neuroprotective etc[159160]. Animal studies have also indicated their potential beneficial effects in dementia[160-162]. Few clinical trials carried out with rosiglitazone and pioglitazone have also shown some promising results in patients with mild to moderate AD and dementia[163-164]. However extensive data remains to be generated to explore full potential of PPAR $\gamma$ agonists in cognitive disorders and $\mathrm{VaD}$.

\section{f.3) Nuclear factor- $\kappa B(N F-\kappa B)$ inhibitor}

The nuclear factor kappa-B (NF-kB) belongs to the family of transcription factors that regulate the induction and resolution of inflammation. NF- $\mathrm{KB}$ promotes through its proinflammatory, pro-adhesion and prooxidant gene transcription[165]. It has also been reported that NF- $\mathrm{kB}$ is involved in amyloid beta-42-induced neuroal cell death and subsequent memory impairment[113]. In aging-induced dementia, there is an activation of NF- $\mathrm{KB}$ which results in the upregulation of genes of pro-inflammatory enzymes $[98,166]$. Furthermore, NF- $\mathrm{kB}$ has been reported to impair spatial learning in mice and reduces long-term potentiation and longterm depression[167-168]. It has been documented that Sodium Diethyl Dithio Carbamate Trihydrate (NDDCT) attenuated L-methionine HHcy-HL (hyperhomocysteinemiahyperlipidemia) induced endothelial dysfunction, learning and memory impairment, oxidative stress levels as well as brain AChE activity[77].

\section{f.4) Endothelin(ET) receptor antagonists}

ET-1 has been reported to induce neurovascular dysfunction in hypoxia condition associated with stroke and dementia[169]. ET receptor antagonists have been shown to provide beneficial effect in various cerebrovascular disorders such as ischemic stroke[170], subarachnoid hemorrhage[171] and moyamoya disease[172]. ET antagonists have been documented to exert anti-inflammatory, antioxidative and neuroprotective effects in animal studies[173,174]. Moreover, it has been suggested that, ET receptor antagonists may be beneficial in the treatment of $\mathrm{AD}[175]$. Studies from our own lab have demonstrated the efficacy of ambrisentan (selective ETA blocker) and Bosentan (dual ETA and ETB receptor blocker) in rat models of vascular dementia[176-177]. However, potential of ET-1 antagonists in $\mathrm{VaD}$ needs further investigation.

\section{f.5) Perlecan}

Perlecan is a heparan sulfate proteoglycan found in the extracellular matrix (ECM) and in the basement membrane of blood vessels and is a particularly attractive target due to its sensitivity to proteolysis after ischemic brain injury[178-179]. It is reported to be involved in tumorigenesis, angiogenesis, cell proliferation, and bone formation[180-181]. Perlecan consists of edonperlecan's bioactive c-terminal domainV (DV), which has both pro-and anti-angiogenic properties[182183]. Recently it has been demonstrated that when DV is administered $24 \mathrm{~h}$ after experimental stroke, it increases periinfarct angiogenesis. So, DV could treat vascular related abnormalities, provide neuroprotective effect in the poststroke brainand shield neurons from injury or death in $\mathrm{VaD}[184]$. In addition it has also reported to improve cognition and attenuate $A \beta$ - induced neurotoxicity[185]. Further it alsobinds to various growth factors includingvascular endothelial growth factor (VEGF), fibroblast growth factor (FGF) and other components such as laminin, fibronectin and collagen IV [186-187].

\section{f.6) Folic acid}

Folic acid or folate is a B vitamin. It is also referred to as vitamin $\mathrm{M}$, vitamin $\mathrm{B}$, vitamin $\mathrm{Bc}$ (or folacin), pteroyl-Lglutamic acid, and pteroyl-L-glutamate[188-189]. It plays a major role in central nervous system development. Folic acid deficiency associated with high homocysteine levels, and leads to neuropsychiatric disorders (depression and dementia). The use of folic acid is suggested to prevent the impairment in cognitive functions, especially in case of dementia[190]. Folacin in recent reports has been suggested to exert beneficial effects in L-methionine induced vascular dementia in rats[77]. Folacin has been shown to possess anti-oxidative effect in Hyperhomocysteinemicanimals[191].

\section{f.7) Nicergoline}

Nicergoline (8-beta-(bromonicotinoylhydroxymethyl)-1,6dimethyl-10alpha-metoxyergoline) is an ergot derivative which has been used clinically in over 50 countries for more than three decades for the treatment of cognitive, affective and behavioral disorders in elderly people. It has a large number of effects which includes actions on neurotransmitters such as 


\section{Indo Global Journal of Pharmaceutical Sciences, 2018; 8(2): 41-54}

acetylcholine, noradrenaline and dopamine, and on intracellular signaling cascades. The Cochrane database has provided meta-analysis data from 11 nicergoline clinical trials with around 1300 patients, half of which received nicergoline and other half received placebo[192-193]. Two studies were carried out, one specifically consisted of patients diagnosed with "multi-infarct dementia" and another study was focused on a population with multi-infarct dementia and Alzheimer's type dementia, there was improved memory (MMSE), global rating (CGI), behavior (SCAG) as a result [133]. So this shows that nicergoline may have a beneficial effect in vascular dementia but further studies are needed to establish efficacy of nicergoline in $\mathrm{VaD}$.

\section{CONCLUSION}

Vascular dementia is taking the attention of the research worldwide. There are many medications available in the market but due to higher toxicity it abolishes the use for patient. This present review provides the recent update on vascular dementia. This would be help full to the researcher to understand the overview about it.

\section{REFERENCES}

1. Venkat P, Chopp M, Chen J. Models and mechanisms of vascular dementia. Exp Neurol. 2015; 272: 97-108.

2. Plassman BL, Langa KM, Fisher GG, Heeringa SG, Wei DR, Ofstedal MB, Steffens DC. Prevalence of dementia in the United States: the aging, demographics, and memory study. Neuroepidemiology. 2007; 29(1-2): 125-132.

3. Hagnell O, Ojesjo L, Rorsman B. Incidence of dementia in the Lund by Study.Neuroepidemiology. 1992; 11(1): 61-66.

4. Prince M, Bryce R, Albanese E, Wimo A, Ribeiro W, Ferri $\mathrm{CP}$. The global prevalence of dementia: a systematic review and metaanalysis. Alzheimers Dement. 2013; 9(1): 63-75.

5. Marshall RS. Effects of altered cerebral hemodynamics on cognitive function. $J$ Alzheimer's Dis. 2012; 32(3): 633-642.

6. Peters R. Blood pressure, smoking and alcohol use, association with vascular dementia. Exp Gerontol. 2012; 47(11): 865-872

7. Montiel JM, Bartholomeu D, Cecato JF, Giraldi MG, Martinelli JE. Comparison in cognitive function in Alzheimer's disease and Vascular Dementia: Contributions to the differential diagnosis. Issues Biol Sci Pharm Res. 2014; 2: 35-39.

8. Pasi M, Poggesi A, Salvadori E, Pantoni L. Post-stroke dementia and cognitive impairment. Stroke. 2012; 30: 65-69.

9. Pohjasvaara T, Leppavuori A, Siira I, Vataja R, Kaste M, Erkinjuntti T. Frequency and clinical determinants of poststroke depression. Stroke. 1998; 29(11): 11-17.

10. Pohjasvaara T, Leskela M, Vataja R, Kalska H, Ylikoski R, Hietanen M, Erkinjuntti T. Post-stroke depression, executive dysfunction and functional outcome. Eur J Neurol. 2002; 9(3): 269-275.

11. Foster V, Oakley AE, Slade JY, Hall R, Polvikoski TM, Burke M, Kalaria RN. Pyramidal neurons of the prefrontal cortex in post-stroke, vascular and other Ageing-related dementias. Brain. 2014; 137(9): 2509-2521.
12. Suvorova I, Shprakh V. Neuroprotective therapy in basic treatment of vascular dementia. Eur Neuropsychopharmacol. 2010; 20(2): 561 .

13. Thal DR, Grinberg LT, Attems J. Vascular dementia: different forms of vessel disorders contribute to the development of dementia in the elderly brain. Exp Gerontol. 2012; 47(11): 816824 .

14. Launer LJ, Hughes TM, White LR. Microinfarcts, brain atrophy, and cognitive function: the Honolulu Asia aging study autopsy study. Ann Neurol. 2011; 70(5): 774-780.

15. Ferrer I. Cognitive impairment of vascular origin: neuropathology of cognitive impairment of vascular origin. J Neurol Sci. 2010; 299(1): 139-149.

16. Smith EE, Schneider JA, Wardlaw JM, Greenberg SM. Cerebral microinfarcts: the invisible lesions.Lancet Neurol. 2012; 11(3): 272-282.

17. Erkinjuntti T, Sulkava R. Diagnosis of multi-infarct dementia. JAlzheimers Dis. 1991; 5(2): 112-121.

18. Lundensia AS, Brun A. Stroke dementia disease and the white dementia. Acta Scientiarum Lundensia. 2015; 1: 1-5.

19. Sari AD, Nyoman R, Bagus KS. Multi-infarct dementia.Mol Neuroscience. 2015, 56(2): 34-47.

20. Erkinjuntti T. Cerebrovascular dementia. CNS Drugs. 1999; 12(1): 35-48.

21. O'Brien J, Erkinjuntti T, Reisberg B, Roman G, Sawada T, Pantoni L, Rockwood K. Vascular cognitive impairment.Lancet Neurol. 2003; 2(2): 89-98.

22. Chui HC. Subcortical ischemic vascular dementia. Neurol clin. 2007; 25(3): 717-740.

23. Mizuno T. Subcortical ischemic vascular dementia: lesson from hereditary cerebral small vessel disease. Brain and Nerve. 2015; 67(4): 403-412.

24. Kalaria RN, Maestre GE, Arizaga R, Friedland RP, Galasko D, Hall K, Prince M. Alzheimer's disease and vascular dementia in developing countries: prevalence, management, and risk factors.Lancet Neurol. 2008; 7(9): 812-826.

25. Ma J, Xiong JY, Hou WW, Yan HJ, Sun Y, Huang SW, Chen Z. Protective effect of carnosine on subcortical ischemic vascular dementia in mice. CNS Neurosci Ther. 2012; 18(9): 745753.

26. Loeb C. Binswanger's disease is not a single entity. Neurol Sci. 2000; 21(6): 343-348.

27. Kitaguchi H, Ihara M, Saiki H, Takahashi R, Tomimoto H. Capillary beds are decreased in Alzheimer's disease, but not in Binswanger's disease. Neurosci Lett. 2007; 417(2): 128-131.

28. Thaje P, Thajeb T, Dai D. Cross-cultural studies using a modified mini mental test for healthy subjects and patients with various forms of vascular dementia. J Clin Neurosci. 2007; 14(3): 236-241.

29. Series H, Esiri M. Vascular dementia: a pragmatic review.Adv Psychiatr Treat.2012; 18(5): 372-380.

30. Appelros P. Cognitive Impairment in Lacunar Strokes.Eur Neurol Rev. 2014; 9(1): 64-67.

31. Arboix A, Blanco-Rojas L. Cognitive impairment in ischaemic lacunar stroke. Eur Neurol Rev. 2013; 8: 144-148.

32. Fisher CM. Lacunar infarcts-a review. Cerebrovasc Dis. $1991 ; 1(6): 311-320$

33. Arboix A, Massons J, Garcia-Eroles L, Targa C, Comes E, Parra O. Clinical predictors of lacunar syndrome not due to lacunar infarction. BMC Neurol. 2010; 10(1): 1.

34. Mohr JP, Grotta JC, Wolf PA, Moskowitz MA, Mayberg MR, Von KR. Stroke: Pathophysiology, Diagnosis, and Management. Elsevier Health Sci. 2011; 7: 485-515. 


\section{Indo Global Journal of Pharmaceutical Sciences, 2018; 8(2): 41-54}

35. Sathe S, Beninati E, Raz E, Inglese M. Development of a lacune: what do we find in CADASIL. Neurology. 2015; 84(14): $2-255$.

36. Tikka S, Baumann M, Siitonen M, Pasanen P, Poyhonen M, Myllykangas L, Kalimo H. CADASIL and CARASIL. Brain Pathol. 2014; 24(5): 525-544.

37. Zea-Sevilla M, Bermejo-Velasco P, Serrano-Heranz R, Calero M. Cerebral autosomal dominant arteriopathy with subcortical infarcts and leukoencephalopathy (CADASIL) associated with a novel C82R mutation in the NOTCH3 gene. J Alzheimer's Dis. 2015; 43(2): 363-367.

38. McVeigh C, Passmore P. Vascular dementia: prevention and treatment. Clin Interv Aging. 2006; 1(3): 229-235.

39. Isella V, Rucci F, Traficante D, Mapelli C, Ferri F, Appollonio IM. The applause sign in cortical and corticalsubcortical dementia. J Neurol. 2013; 260(4): 99-103.

40. Xiong L, Reijmer YD, Charidimou A, Cordonnier C, Viswanathan A. Intracerebral hemorrhage and cognitive impairment.Biochim Biophys Acta. 2016; 1862(5): 939-944.

41. Caplan LR. Intracerebral haemorrhage.Lancet. 1992; 339(8794): 656-658

42. Broderick JP, Brott TG, Duldner JE, Tomsick T, Huster G. Volume of intracerebral hemorrhage. A powerful and easy-to-use predictor of 30-day mortality. Stroke. 1993; 24(7): 987-993.

43. Jamieson EI, Newman D, Metcalf AK, Naguib MF, Saada J, Potter JF, Myint PK. Dementia is strongly associated with 90day mortality in lobar cerebral amyloid angiopathy related intracerebral haemorrhage. J Neurol Sci. 2012; 322(1): 161-165.

44. Furlan AJ, Whisnant JP, Elveback LR. The decreasing incidence of primary intracerebral hemorrhage: a population study. Ann Neurol. 1979; 5(4): 367-373.

45. Kase CS, Williams JP, Wyatt DA, Mohr JP. Lobar intracerebral hematomas Clinical and CT analysis of 22 cases. Neurology. 1982; 32(10): 46-78.

46. O'Donnell HC, Rosand J, Knudsen KA, Furie K L, Segal AZ, Chiu RI, Greenberg SM. Apolipoprotein E genotype and the risk of recurrent lobar intracerebral hemorrhage. N Engl J Med. 2000; 342(4): 240-245.

47. Mohan S, Ahmad AS, Glushakov A, Chambers C, Dore S. Putative role of prostaglandin receptor in intracerebral hemorrhage. Front Neurol. 2012; 3: 145.

48. Commichau C. Hypoxic-Ischemic encephalopathy, in Neurological therapeutics principles and practice. 2006; 74(5): 528-537.

49. Garrido MM, Bayarri JG. Hypoxic Encephalopathy. 2012. (INTECH Open Access Publisher)

50. Calvert JW, Zhang JH. Pathophysiology of an hypoxicischemic insult during the perinatal period. Neurol Res. 2005; 27(3): 246-260.

51. Busl KM, Greer DM. Hypoxic-ischemic brain injury: Pathophysiology, neuropathology and mechanisms. Neuro Rehabilitation. 2010; 26(1): 5-13.

52. Roman GC, Erkinjuntti T, Wallin A, et al. Subcortical ischaemic vascular dementia. Lancet Neurol. 2002; 1: 426-436.

53. Kim HJ, Kim J, Cho H, Ye BS, Yoon CW, Noh Y, Lee $\mathrm{KH}$. Individual subject classification of mixed dementia from pure subcortical vascular dementia based on subcortical shape analysis. PLoS One. 2013; 8(10): 75602.

54. Arboix A. Lacunar infarct and cognitive decline. Expert Rev Neurother. 2011; 11(9): 1251-1254.

55. Lipsanen JH, Schmidt R, Fazekas $\mathrm{F}$ et al. Brain atrophy accelerates cognitive decline in cerebral small vessel disease: The LADIS study. Neurology.2012; 78: 1785-92.
56. Tomimoto H. Subcortical vascular dementia. Neurosci Res. 2011; 71(3): 193-199.

57. Chen JH, Lin KP, Chen YC. Risk factors for dementia.J Formos Med Assoc. 2009; 108(10): 754-764.

58. Barnes DE, Yaffe K. The projected effect of risk factor reduction on Alzheimer's disease prevalence.Lancet Neurol. 2011; 10(9): 819-828.

59. Exalto LG, Whitmer RA, Kappele LJ, Biessels GJ. An update on type 2 diabetes, vascular dementia and Alzheimer's disease. Exp Gerontol. 2012; 47(11): 858-864.

60. Peters R. Blood pressure, smoking and alcohol use, association with vascular dementia. Exp Gerontol. 2012; 47(11): 865-872.

61. Marshall RS. Effects of altered cerebral hemodynamics on cognitive function. J Alzheimer's Dis. 2012; 32(3): 633-642.

62. Ruitenberg A, Ott A, van Swieten JC, Hofman A, Breteler MM. Incidence of dementia: does gender make a difference?.Neurobiol of Aging. 2001; 22(4): 575-580.

63. Biessel GJ, Staekenborg S, Brunner E, Brayne C, Scheltens P. Risk of dementia in diabetes mellitus: a systematic review.Lancet Neurol. 2006; 5(1): 64-74.

64. Strachan MW, Reynolds RM, Marioni RE, Price JF. Cognitive function, dementia and type 2 diabetes mellitus in the elderly. Nat Rev Endocrinol. 2011; 7(2): 108-114.

65. Kloppenborg RP, van den Berg E, Kappelle LJ, Biessels GJ. Diabetes and other vascular risk factors for dementia: which factor matters most? A systematic review. Eur J Pharmacol. 2008; 585(1): 97-108

66. Diamond, J. A report on Alzheimer's disease and current research. Alzheimer Society of Canada. 2011

67. Takeda M, Martinez R, Kudo T, Tanaka T, Okochi M, Tagami S, Cacabelos R. Apolipoprotein E and central nervous system disorders: reviews of clinical findings. Psychiatry Clin Neurosci. 2010; 64(6): 592-607.

68. Irie F, Fitzpatrick AL, Lopez OL, Kuller LH, Peila R, Newman AB, Launer LJ. Enhanced risk for Alzheimer disease in persons with type 2 diabetes and APOE $\varepsilon 4$ : The Cardiovascular Health Study Cognition Study. Arch Neurol. 2008; 65(1): 89-93.

69. Dore GA, Elias MF, Robbins MA, Elias PK, Nagy Z. Presence of the APOE $\varepsilon 4$ allele modifies the relationship between type 2 diabetes and cognitive performance: the Maine-Syracuse study. Diabetologia. 2009; 52(12): 51-60.

70. Luitse MJ, Biessels GJ, Rutten GE, Kappelle LJ. Diabetes, hyperglycaemia, and acute ischaemic stroke. Lancet Neurol. 2012; 11(3): 261-271.

71. Nagai M, Hoshide S, Kario K. Hypertension and Dementia. Am J Hypertens. 2010; 23(2): 116-24.

72. Lorenza MM, Salvetti M, Belotti E, Paini A, Rosei CA, Aggiusti $\mathrm{C}$, et al. Effects of barnidipine in comparison with hydrochlorthiazideon endothelial function as assessed by flow mediated vasodilatation in hypertensive patients. Blood Press. 2011; 20(4): 244-51.

73. Yang Q, Xue HM, Wong WT, Tian XY, Huang Y, Tsui SK, Tobias S. AVE3085, an enhancer of endothelial nitric oxide synthase, restores endothelial function and reduces blood pressure in spontaneously hypertensive rats. $B r J$ Pharmacol. 2011; 163(5): $1078-1085$

74. Kherada N, Heimowitz T, Rosendorff C. Antihypertensive therapies and cognitive function: a review. Curr Hypertens Rep. 2015; 17(10): 1-7.

75. Kandlikar SS, Fink GD. Mild DOCA-salt hypertension: sympathetic system and role of renal nerves. Am J Physiol Heart Circ Physiol. 2011; 300(5): 81-87.

76. Ocaranza MP, Rivera P, Novoa U, Pinto M, Gonzalez L, Chiong M, Jalil JE. Rho kinase inhibition activates the 


\section{Indo Global Journal of Pharmaceutical Sciences, 2018; 8(2): 41-54}

homologous angiotensin-converting enzyme-angiotensin-(1-9) axis in experimental hypertension. J Hypertens. 2011; 29(4): 706715 .

77. Sharma B, Singh N. Defensive effect of natrium diethyldithiocarbamate trihydrate (NDDCT) and lisinopril in DOCA-salt hypertension-induced vascular dementia in rats. Psychopharmacology. 2012; 223(3): 307-317.

78. Verhaaren BF, Vernooij MW, de Boer R, Hofman A, Niessen WJ, van der Lugt A, Ikram MA. High blood pressure and cerebral white matter lesion progression in the general population. Hypertension. 2013; 61(6): 1354-1359.

79. Ochi N, Kohara K, Tabara Y, Nagai T, Kido T, Uetani E, Miki, T. Association of central systolic blood pressure with intracerebral small vessel disease in Japanese. Am J Hypertens. 2010; 23(8): 889-894.

80. Van Oijen M, Jan de Jong F, Witteman J, Hofman A, Koudstaal PJ, Breteler M. Atherosclerosis and risk for dementia. Ann Neurol. 2007; 61(5): 403-410.

81. Hanon O, Haulon S, Lenoir H, Seux ML, Rigaud AS, Safar M, Forette F. Relationship between arterial stiffness and cognitive function in elderly subjects with complaints of memory loss. Stroke. 2005; 36(10): 93-97.

82. Irundika HK, Dias MC, Polidori HR. Hypercholesterolaemia-induced oxidative stress at the blood brain barrier.Biochem Soc Trans. 2014; 42(4): 1-15.

83. Weisgraber KH, Rall SC, Mahley RW. Human E apoprotein heterogeneity. Cysteine-arginine interchanges in the amino acid sequence of the apo-E isoforms. J Biol Chem. 1981; 256(17): 83-90.

84. Michikawa M, Fan QW, Isobe I, Yanagisawa K. Apolipoprotein E exhibits isoform-specific promotion of lipid efflux from astrocytes and neurons in culture. J Neurochem. 2000; 74(3): 28-46.

85. Liu CC, Kanekiyo T, Xu H, Bu G. Apolipoprotein E and Alzheimer disease: risk, mechanisms and therapy. Nat Rev Neurol. 2013; 9(2): 106-118.

86. Rohn TT. Is apolipoprotein E4 an important risk factor for vascular dementia. Int J Clin Exp Pathol. 2014; 7(7): 4-11.

87. Luchsinger JA, Tang MX, Shea S, Mayeux R. Caloric intake and the risk of Alzheimer disease. Arch Neurol. 2002; 59(8): 1258-1263.

88. Laitinen MH, Ngandu T, Rovio S, Helkala EL, Uusitalo U, Viitanen M, Kivipelto M. Fat intake at midlife and risk of dementia and Alzheimer's disease: a population-based study. Dement Geriatr Cogn Disord. 2006; 22(1): 99-107.

89. McGuinness B, Carson R, Barrett SL, Craig D, Passmore AP. Apolipoprotein $\varepsilon 4$ and neuropsychological performance in Alzheimer's disease and vascular dementia. Neurosci Lett. 2010; 483(1): 62-66.

90. Tyagi SC, Lominadze D, Roberts AM. Homocysteine in microvascular endothelial cell barrier permeability. Cell Biochem Biophys. 2005; 43(1): 37-44.

91. Bhatia P, Gupta S, Sharma S. Homocysteine Excess and Vascular Endothelium Dysfunction: Delineating the Pathobiological Mechanisms. Int J Pharmacol. 2014; 10(4): 200212.

92. Murakami H, Iemitsu M, Sanada K, Gando Y, Ohmori Y, Kawakami R, Miyachi, M. Associations among objectively measured physical activity, fasting plasma homocysteine concentration, and MTHFR C677T genotype. Eur J Appl Physiol. 2011; 111(12), 2997-3005.

93. Brustolin S, Giugliani R, Felix TM. Genetics of homocysteine metabolism and associated disorders. Braz J Med Biol Res. 2010; 43(1): 1-7.
94. Rodionov RN, Dayoub $\mathrm{H}$, Lynch $\mathrm{C} \mathrm{M}$, Wilson KM, Stevens JW, Murry DJ, Baumbach GL. Overexpression of dimethylarginine dimethylaminohydrolase protects against cerebral vascular effects of hyperhomocysteinemia. Circulation Res. 2010; 106(3): 551-558.

95. Ansari R, Mahta A, Mallack E, Luo JJ. Hyperhomocysteinemia and neurologic disorders: a review. J Clin Neurol. 2014; 10(4): 281-288.

96. Abahji TN, Nill L, Ide N, Keller C, Hoffmann U, Weiss N. Acute hyperhomocysteinemia induces microvascular and macrovascular endothelial dysfunction.Arch Med Res.2007; 38(4): 411-416.

97. Gelecek N, Teoman N, Ozdirenc M, Pinar L, Akan P, Bediz C, Kozan O. Influences of acute and chronic aerobic exercise on the plasma homocysteine level. Ann Nutr Metab. 2007; 51(1): 53-58.

98. Kim DB, Oh YS, Yoo KD, Lee JM, Park CS, Ihm SH, Rho TH. Passive Smoking in Never-Smokers Is Associated With Increased Plasma Homocysteine Levels Analysis of NHANES III Data. Int Heart J. 2010; 51(3): 183-187.

99. Molina-Lopez J, Molina JM, Chirosa LJ, Florea DI, Sáez, L, Planells E. Effect of folic acid supplementation on homocysteine concentration and association with training in handball players. J Int Soc Sports Nutr. 2013; 10(1): 1.

100. Renke M, Tylicki L, Rutkowski P, Larczynski W, Neuwelt A, Aleksandrowicz E, Rutkowski B. The effect of N-acetylcysteine on blood pressure and markers of cardiovascular risk in nondiabetic patients with chronic kidney disease: A placebo-cotrolled, randomized, cross-over study. Med Sci Monit. 2010; 16(7): I13I18.

101. Matsui T, Yokoyama A, Matsushita S, Kozaki K, Higuchi, S. Alcohol-related dementia.Japanese J Clin Med. 2014; 72(4): 749-756.

102. Gupta S, Warner J. Alcohol-related dementia: a 21stcentury silent epidemic. Br J Psychiatry. 2008; 193(5): 351-353.

103. Kimm H, Lee PH, Shin YJ, Park KS, Jo J, Lee Y, Jee SH. Mid-life and late-life vascular risk factors and dementia in Korean men and women. Arch Gerontol Geriatr. 2011; 52(3): 117-122.

104. Zhong G, Wang Y, Zhang Y, Guo JJ, Zhao Y. Smoking is associated with an increased risk of dementia: A meta-analysis of prospective cohort studies with investigation of potential effect modifiers. PLoS One. 2015; 10(3): 18-33.

105. Butterfield DA, Perluigi M, Sultana R. Oxidative stress in Alzheimer's disease brain: new insights from redox proteomics. Eur J Pharmacol. 2006; 545(1): 39-50.

106. McKenzie J, Bhatti L, d'Espaignet ET. WHO Tobacco Knowledge Summaries: Tobacco and Dementia. Geneva: WorldHealth Organization. 2014.

107. Korczyn AD, Vakhapova V, Grinberg LT. Vascular dementia. J Neurol Sci. 2012; 322(1): 2-10.

108. Chandra M, Anand KS. Obesity in Indian subjects with vascular dementia. Int J Adv Med. 2015; 2(2): 147-151.

109. Beydoun MA, Beydoun HA, Wang Y. Obesity and central obesity as risk factors for incident dementia and its subtypes: a systematic review and meta-analysis. ObesRev. 2008; 9(3): 204218 .

110. Fitzpatrick AL, Kuller LH, Lopez OL, Diehr P, O’Meara ES, Longstreth WT, Luchsinger JA. Midlife and late-life obesity and the risk of dementia: cardiovascular health study. Arch Neurol. 2009; 66(3): 336-342.

111. Wolk R, Berger P, Lennon RJ, Brilakis ES, Johnson BD, Somers VK. Plasma leptin and prognosis in patients with established coronary atherosclerosis. J Am Coll Cardiol. 2004; 44(9): 1819-1824. 


\section{Indo Global Journal of Pharmaceutical Sciences, 2018; 8(2): 41-54}

112. Corder EH, Saunders AM, Strittmatter WJ, Schmechel DE, Gaskell PC, Small G, Pericak-Vance MA. Gene dose of apolipoprotein E type 4 allele and the risk of Alzheimer's disease in late onset families. Science. 1993; 261(5123): 921-923.

113. Kim SM, Lee SY, Yuk DY, Moon DC, Choi SS, Kim Y, Hong JT. Inhibition of NF-kB by ginsenoside Rg3 enhances the susceptibility of colon cancer cells to docetaxel. Arch Pharm Res. 2009; 32(5): 755-765.

114. Ayata C. CADASIL Experimental Insights From Animal Models. Stroke. 2010; 41(1): 129-134.

115. Du Y, Dodel RC, Eastwood BJ, Bales KR, Gao F, Lohmuller F, Hake A. Association of an interleukin $1 \alpha$ polymorphism with Alzheimer's disease. Neurol. 2000; 55(4): 480-484.

116. Enciu AM, Popescu BO. Is there a causal link between inflammation and dementia. Biomed Res Int.2013; 34(6): 23-43.

117. Vinters HV, Ellis WG, Zarow C, Zaias BW, Jagust WJ, Mack WJ, Chui HC. Neuropathologic substrates of ischemic vascular dementia. JNeuropathol Exp Neurol. 2000; 59(11): 931945.

118. Erkinjuntti T, Gustavo R, Gauthier S. Treatment of vascular dementia-evidence from clinical trials with cholinesterase inhibitors. Neurol Sci. 2004; 226: 63-66.

119. Selden NR, Gitelman DR, Salamon-Murayama N, Parrish TB, Mesulam MM. Trajectories of cholinergic pathways within the cerebral hemispheres of the human brain. Brain. 1998; 121(12): 49-57.

120. Togashi H, Matsumoto M, Yoshioka M, Hirokami M, Minami M, Saito H. Neurochemical profiles in cerebrospinal fluid of stroke-prone spontaneously hypertensive rats. Neurosci Lett. 1994; 166(1): 117-120.

121. Kimura S, Saito H, Minami M, Togashi H, Nakamura N, Nemoto M, Parvez HS. Pathogenesis of vascular dementia in stroke-prone spontaneously hypertensive rats. Toxicology. 2000; 153(1): 167-178.

122. Ratnatunge SS, De Silva VA. Management of dementia: review of evidence.J Ceylon College Physicians. 2015; 46: 24-28.

123. Molino I, Colucci L, Fasanaro AM, Traini E, Amenta F. Efficacy of memantine, donepezil, or their association in moderatesevere Alzheimer's disease: A review of clinical trials. The Scientific World Journal.2013; 26(9): 25-32.

124. Christensen DD. Higher-dose (23 mg/day) Donepezil formulation for the treatment of patients with moderate-to-severe Alzheimer's disease. Postgrad Med. 2012; 124(6): 110-116.

125. Khateb A, Ammann J, Annoni JM, Diserens K. Cognitionenhancing effets of donepezil in traumatic brain injury. Eur Neurol. 2005; 54(1): 39-45.

126. Kwon KJ, Kim MK, Lee EJ, Kim JN, Choi BR, Kim SY, Han SH. Effects of Donepezil, an acetylcholinesterase inhibitor, on neurogenesis in a rat model of vascular dementia. J Neurol Sci. 2014; 347(1): 66-77.

127. Kotani S, Yamauchi T, Teramoto T, Ogura H. Donepezil, an acetylcholinesterase inhibitor, enhances adult hippocampal neurogenesis.Chem Biol Interact. 2008; 175(1): 227-230.

128. Kotani S, Yamauchi T, Teramoto T, Ogura $H$. Pharmacological evidence of cholinergic involvement in adult hippocampal neurogenesis in rats. Neuroscience. 2006; 142(2): 505-514.

129. Birks J, Craig D. Galantamine for vascular cognitive impairment. Cochrane Libr. 2006; 25(4): 47-46.

130. Kavirajan H, Schneider LS. Efficacy and adverse effects of cholinesterase inhibitors and memantine in vascular dementia: a meta-analysis of randomised controlled trials.Lancet Neurol. 2007; 6(9): 782-792.
131. Birks J, McGuinness B, Craig D. Rivastigmine for vascular cognitive impairment. Cochrane Libr. 2013; 5: 44-49.

132. Auchus AP, Brashear HR, Salloway S, Korczyn AD, De Deyn PP, Gassmann-Mayer C. Galantamine treatment of vascular dementia A randomized trial. Neurol. 2007; 69(5): 448-458.

133. Baskys A, Hou AC. Vascular dementia: pharmacological treatment approaches and perspectives. Clin Interv Aging.2007; 2(3): 327-335.

134. Moretti R, Torre P, Antonello RM, Cazzato G, Bava A. Rivastigmine in subcortical vascular dementia: a randomized, controlled, open 12-month study in 208 patients. Am J Alzheimers Dis Other Demen.2003; 18(5): 265-272.

135. McGuinness B, Craig D, Bullock R, Malouf R, Passmore P. Statins for the treatment of dementia. Cochrane Database Syst. Rev. 2014; 8(7): 7514.

136. Wassmann S, Laufs U, Baumer AT, Müller K, Ahlbory K, Linz W, Nickenig G. HMG-CoA reductase inhibitors improve endothelial dysfunction in normocholesterolemic hypertension via reduced production of reactive oxygen species. Hypertension. 2001; 37(6): 1450-1457.

137. Giannopoulos S, Katsanos AH, Kosmidou M, Tsivgoulis G. Statins and vascular dementia: a review.J Alzheimers Dis. 2014; 42(3): 315-320.

138. Olivares DK, Deshpande V, Shi YK, Lahiri DH, Greig NT, Rogers J, Huang X. N-methyl D-aspartate (NMDA) receptor antagonists and memantine treatment for Alzheimer's disease, vascular dementia and Parkinson's disease. Curr Alzheimer Res. 2012; 9(6): 746-758.

139. Lai TW, Zhang S, Wang YT. Excitotoxicity and stroke: identifying novel targets for neuroprotection. Prog Neurobiol. 2014; 115: 157-188.

140. Areosa SA, Sherriff F, McShane R. Memantine for dementia. Cochrane Database Syst Rev. 2006; 19(2): 31-54.

141. Mobius HJ, Stoffler A. Memantine in vascular dementia. Int Psychogeriatr. 2003; 15(1): 207-213.

142. Nazish S, Soomro BA, Alvi S. Efficacy of memantine on cognitive functions of patients with moderate vascular dementia. Pakistan J Neurol Sci. 2015; 10(1): 6-9.

143. Ricote M, Li AC, Willson TM, Kelly CJ, Glass CK. The peroxisome proliferator-activated receptor- $\gamma$ is a negative regulator of macrophage activation. Nature. 1998; 39(2): 79-82.

144. In'T Veld BA, Ruitenberg A, Hofman A, Launer LJ, van Duijn CM, Stijnen T, Stricker BH. Nonsteroidal antiinflammatory drugs and the risk of Alzheimer's disease.N Engl J Med.2001; 345(21): 15-21.

145. Breitner JC, Welsh KA, Helms MJ, Gaskell PC, Gau BA, Roses AD, Saunders AM. Delayed onset of Alzheimer's disease with nonsteroidal anti-inflammatory and histamine $\mathrm{H} 2$ blocking drugs. Neurobiol Aging. 1995; 16(4): 523-530.

146. Meyer JS, Rogers RL, McClintic K, Mortel KF, Lotfi, J. Randomized Clinical Trial of Daily Aspirin Therapy in Multi-Infarct Dementia. J Ame Geriatr Soc. 1989; 37(6): 549-555.

147. Bour AMJJ, Westendorp RGJ, Laterveer JC, Bollen ELEM, Remarque EJ. Interaction of indomethacin with cytokine production in whole blood. Potential mechanism for a brainprotective effect. Exp Gerontol. 2000; 35(8): 17-24.

148. Ramchandra R, Barrett CJ, Malpas SC. Nitric oxide and sympathetic nerve activity in the control of blood pressure. Clin Exp Pharmacol Physiol. 2005; 32(5-6): 440-446.

149. O'rourke, MF, Hashimoto J. Mechanical factors in arterial aging: a clinical perspective.J Am Coll Cardiol. 2007; 50(1): 1-13.

150. Khachaturian AS, Zandi PP, Lyketsos CG, Hayden KM, Skoog I, Norton MC, Breitner JC. Antihypertensive medication use and incident Alzheimer disease: the Cache County Study. Arch Neurol. 2006; 63(5): 686-692. 


\section{Indo Global Journal of Pharmaceutical Sciences, 2018; 8(2): 41-54}

151. Chiu WC, Ho WC, Lin MH, Lee HH, Yeh YC, Wang JD. Angiotension receptor blockers reduce the risk of dementia. J Hypertens. 2014; 32(4): 938-947.

152. Birks J, Lopez-Arrieta J. Nimodipine for primary degenerative, mixed and vascular dementia.Cochrane Libr. 2002; 3: 147 .

153. Bayer AJ, Bokonjic R, Booya NH, Demarin V, Ersmark B, Fairbairn AF, Haugaar K. European pentoxifylline multi-infarct dementia study. Eur Neurol. 1996; 36(5): 315-321.

154. Michael CS, Callahan CM. The efficacy of pentoxifylline in the treatment of vascular dementia: a systematic review. Alzheimer Dis Assoc Disord. 2003; 17(1): 46-54.

155. Kumar A, Kumar A, Jaggi AS, Singh N. Efficacy of Cilostazol a selective phosphodiesterase-3 inhibitor in rat model of Streptozotocin diabetes induced vascular dementia.Pharmacol Biochem Behav. 2015; 135: 20-30.

156. Francis SH, Blount MA, Corbin JD. Mammalian cyclic nucleotide phosphodiesterases: molecular mechanisms and physiological functions. Physiol Rev. 2011; 91(2): 651-690.

157. Peixoto CA, Nunes AKS, Garcia-Osta A. Phosphodiesterase-5 inhibitors: Action on the signaling pathways of neuroinflammation, neurodegeneration, and cognition. Mediators of Inflamm. 2015; 9(40): 207-218.

158. Akar F, Mutlu O, Celikyurt IK, Ulak G, Erden F, Bektas E, Tanyeri P. Effects of rolipram and zaprinast on learning and memory in the Morris water maze and radial arm maze tests in naive mice. Drug Res. 2015; 65(02): 86-90.

159. Luo Y, Yin W, Signore AP, Zhang F, Hong Z, Wang S, Chen J. Neuroprotection against focal ischemic brain injury by the peroxisome proliferator-activated receptor- $\gamma$ agonist rosiglitazone. J Neurochem. 2006; 97(2): 435-448.

160. Sharma B, Singh N. Behavioral and biochemical investigations to explore pharmacological potential of PPARgamma agonists in vascular dementia of diabetic rats.Pharmacol Biochem Behav. 2011; 100(2): 320-329.

161. Rinwa P, Kaur B, Jaggi AS, Singh N. Involvement of PPAR-gamma in curcumin-mediated beneficial effects in experimental dementia. Naunyn-Schmiedeberg's Arch Pharmacol. 2010; 81(6): 529-539.

162. Sain H, Sharma B, Jaggi AS, Singh N. Pharmacological investigations on potential of peroxisome proliferator-activated receptor-gamma agonists in hyperhomocysteinemia-induced vascular dementia in rats. Neuroscience. 2011; 192: 322-333.

163. Sato $T$, Hanyu $H$, Hirao $K$, Kanetaka H, Sakurai H, Iwamoto T. Efficacy of PPAR- $\gamma$ agonist pioglitazone in mild Alzheimer disease. Neurobiol Aging. 2011; 32(9): 26-33.

164. Valenti MT, Garbin U, Pasini A, Zanatta M, Stranieri C, Manfro S, Dalle Carbonare L. Role of ox-PAPCs in the differentiation of mesenchymal stem cells (MSCs) and Runx2 and PPAR $\gamma 2$ expression in MSCs-like of osteoporotic patients. PLoS One. 2011; 6(6): 20363.

165. Oeckinghaus A, Ghosh S. The NF- $\kappa$ B family of transcription factors and its regulation. Cold Spring Harb Perspect Biol.2009; 1(4): 34.

166. Meffert MK, Chang JM, Wiltgen BJ, Fanselow MS, Baltimore D. NF- $\mathrm{BB}$ functions in synaptic signaling and Behavior. Nat Neurosci. 2003; 6(10): 1072-1078.

167. Fridmacher V, Kaltschmidt B, Goudeau B, Ndiaye D, Rossi FM, Pfeiffer J, Memet S. Forebrain-specific neuronal inhibition of nuclear factor- $\mathrm{\kappa B}$ activity leads to loss of neuroprotection. J Neurosci. 2003; 23(28): 3-8.

168. Kaltschmidt B, Ndiaye D, Korte M, Pothion S, Arbibe L, Prullage M, Kaltschmidt $\mathrm{C}$. NF- $\kappa \mathrm{B}$ regulates spatial memory formation and synaptic plasticity through protein kinase A/CREB signaling. Mol Cell Biol. 2006; 26(8): 36-46.
169. Capone C, Faraco G, Coleman C, Young CN, Pickel VM, Anrather J, Iadecola C. Endothelin 1-dependent neurovascular dysfunction in chronic intermittent hypoxia. Hypertension. 2012; 60(1): 106-113.

170. Kaundal RK, Deshpande TA, Gulati A, Sharma SS. Targeting endothelin receptors for pharmacotherapy of ischemic strokescenario and future perspectives. Drug Discov Today. 2012; 17(13): 793-804.

171. Komotar RJ, Starke RM, Connolly ES. The effect of endothelin receptor antagonist on vasospasm following aneurismal subarachnoid hemorrhage. Neurosurgery. 2011; 69(6): 4-13.

172. Gupta SK, Saxena A, Singh U, Arya, DS. Bosentan, the mixed $\mathrm{ET}_{\mathrm{A}}-\mathrm{ET}_{\mathrm{B}}$ endothelin receptor antagonist, attenuated oxidative stress after experimental myocardial ischemia and reperfusion. Mol Cell Biochem. 2005; 275(1-2): 67-74.

173. Esiri MM. The interplay between inflammation and neurodegeneration in CNS disease. J Neuroimmunol. 2007; 184(1): 4-16.

174. Chen Y, Hanaoka MASAYUKI, Droma YUNDEN, Chen PING, Voelkel NF, Kubo KEISHI. Endothelin-1 receptor antagonists prevent the development of pulmonary emphysema in rats. Eur Respir J. 2010; 35(4): 904-912.

175. Palmer J, Love S. Endothelin receptor antagonists: Potential in Alzheimer's disease. Pharmacol Res. 2011; 63(6): 525531.

176. Mangat GS, Jaggi AS, Singh N. Ameliorative effect of a selective endothelin $\mathrm{ET}_{\mathrm{A}}$ receptor antagonist in rat model of $\mathrm{L}$ methionine-induced vascular dementia. Korean J Physiol Pharmacol. 2014; 18(3): 201-209.

177. Singh G, Sharma B, Jaggi AS, Singh N. Efficacy of Bosentan, a dual ET ${ }_{\mathrm{A}}$ and $\mathrm{ET}{ }_{\mathrm{B}}$ endothelin receptor antagonist, in experimental diabetes induced vascular endothelial dysfunction and associated dementia in rats. Pharmacol Biochem Behav. 2014; 124: 27-35.

178. Fukuda S, Fini CA, Mabuchi T, Koziol JA, Eggleston LL, Del Zoppo GJ. Focal cerebral ischemia induces active proteases that degrade microvascular matrix. Stroke. 2004; 35(4): 998-1004.

179. Marcelo A, Bix G. The potential role of perlecan domain V as novel therapy in vascular dementia. Metab Brain Dis. 2015; 30(1): 1-5.

180. Lozzo RV, San Antonio JD. Heparan sulfate proteoglycans: heavy hitters in the angiogenesis arena. J Clin Invest. 2001; 108(3): 349-355.

181. Mongiat M, Sweeney SM, San Antonio JD, Fu J, Iozzo RV. Endorepellin, a novel inhibitor of angiogenesis derived from the $\mathrm{C}$ terminus of perlecan. J Biol Chem. 2003; 278(6): 38-49.

182. Farach-Carson MC, Carson DD. Perlecan-a multifunctional extracellular proteoglycan scaffold. Glycobiol. 2007; 17(9): 897905.

183. Roberts J, Kahle MP, Bix GJ. Perlecan and the blood-brain barrier: beneficial proteolysis?.Front Pharmacol. 2012; 3: 155.

184. Lee B, Clarke D, Al Ahmad A, Kahle M, Parham C, Auckland L, Fertala A. Perlecan domain V is neuroprotective and proangiogenic following ischemic stroke in rodents. J Clin Invest. 2011; 121(8): 5-23.

185. Wright S, Parham C, Lee B, Clarke D, Auckland L, Johnston J, Bix G. Perlecan domain V inhibits $\alpha 2$ integrinmediated amyloid- $\beta$ neurotoxicity. Neurobiol Aging. 2012; 33(7): $1379-1388$

186. Lozzo RV, San Antonio JD. Heparan sulfate proteoglycans: heavy hitters in the angiogenesis arena. J Clin Invest. 2001; 108(3): 349-355.

187. Jiang X, Multhaupt H, Chan E, Schaefer L, Schaefer RM, Couchman JR. Essential contribution of tumor-derived perlecan to 
Indo Global Journal of Pharmaceutical Sciences, 2018; 8(2): 41-54

epidermal tumor growth and angiogenesis. J Histochem Cytochem. 2004; 52(12): 75-90.

188. Ural Serdar H. Folic Acid and Pregnancy. Kid's Health. 2008.

189. Weil and Andrew. Supplements and Herbs (Vitamin B9-Folate).2014.

190. Reynolds EH. Folic acid, ageing, depression, and dementia. BMJ. 2002; 24(5): 12-25.

191. Kolling J, Scherer EB, Da Cunha AA, Da Cunha MJ, Wyse AT. Homocysteine induces oxidative-nitrative stress in heart of rats: prevention by folic acid. Cardiovasc Toxicol. 2011; 11(1): 6773.

192. Fioravanti M, Yanagi M. Cytidinediphosphocholine (CDP-choline) for cognitive and behavioural disturbances associated with chronic cerebral disorders in the elderly. Cochrane Libr.2005; 21(3): 36-45.

193. Winblad B, Fioravanti M, Dolezal T, Logina I, Milanov IG, Popescu DC, Solomon A. Therapeutic use of nicergoline. Clin Drug Investig. 2008; 28(9): 533-552.

Indo Global Journal of Pharmaceutical Sciences( ISSN 22491023 ; UGC Journal No.: 44477; CODEN- IGJPAI; NLM ID: 101610675) indexed and abstracted in EMBASE(Elsevier), UGC Journal List, National Library of Medicine (NLM) Catalog, Elsevier( EMBASE), ResearchGate, Publons, CAS (ACS), Index Copernicus, Google Scholar and many more. For further details, visit http://iglobaljournal.com 